\author{
Aleksandra Wrona \\ Wroclaw University of Economics and Business \\ e-mail: aleksandra.wrona@ue.wroc.pl \\ ORCID: 0000-0001-6064-5669
}

\title{
EMPOWERING CITIZENS IN THE CONTEXT OF DELIBERATION PROCESSES
}

\section{WZMACNIANIE POZYCJI OBYWATELI W KONTEKŚCIE PROCESÓW DELIBERACYJNYCH}

DOI: $10.15611 / \mathrm{br} .2021 .1 .11$

JEL Classification: O35, P25, Z1

\section{(C) 2021 Aleksandra Wrona}

This work is licensed under the Creative Commons Attribution-ShareAlike 4.0 International License. To view a copy of this license, visit http://creativecommons.org/licenses/by-sa/4.0/

Quote as: Wrona, A. (2021). Empowering citizens in the context of deliberation processes. Biblioteka Regionalisty. Regional Journal, (21).

\begin{abstract}
Different processes in creating policies of development can be observed, some of which need to be supported. One of the most important issues of new policies is empowering citizens provided by various methods. The research is based on literature studies that show how broad this subject is. Other methods include statistical analyses which made it possible to perceive a correlation between different factors and a benchmark based on the example of the deliberation process in a project prepared by NGOs and the municipality of Warsaw. The aim of the research was to describe the relations and connections between empowering citizens, the deliberation processes and building trust in the local authorities. An interesting outcome of the research was creating a recommendation for policy makers based on the observation that building a dialogue between local governance and citizens can be significant for future sustainable development.
\end{abstract}

Keywords: empowering citizens, deliberation processes, decision-making, urban policies, social participation.

Streszczenie: Różne procesy mają wpływ na tworzenie polityk rozwoju, które czasami wymagają wsparcia. Jedną z najważniejszych kwestii nowych polityk jest wzmacnianie pozycji obywateli, co można zapewnić poprzez wykorzystanie różnych metod. Przeprowadzone badania opierają się na stu- 
diach literaturowych, które pokazują, jak szeroka jest to tematyka. Kolejną metodą badawczą są analizy statystyczne, które pozwoliły dostrzec korelację między różnymi czynnikami, oraz benchmark bazujący na przykładzie procesu deliberacji w projekcie przygotowanym przez organizacje pozarządowe oraz władze Warszawy. Celem badań było opisanie relacji i powiązań między wzmacnianiem pozycji obywateli, procesami deliberacji i budowaniem zaufania do władz. Ciekawym wynikiem badania była obserwacja wskazująca, że budowanie dialogu między lokalnymi władzami a obywatelami może mieć znaczenie dla przyszłego zrównoważonego rozwoju.

Słowa kluczowe: wzmacnianie pozycji obywateli, procesy deliberacyjne, procesy decyzyjne, polityki miejskie, partycypacja społeczna.

\section{Introduction}

According to the latest development strategies, increasing relevance is given to the participation of citizens in policy-making.

Citizens, as the users of the space (local or regional), are seen to be in need of empowerment. Statements linked to this issue can be found in documents such as Sustainable Development Goals and the priorities of the new Cohesion Policy. In the case of equalizing opportunities, creating responsible policies is most essential.

The empowerment of citizens may be conducted in different ways. One of them is the deliberation process, which can also be conducted in various forms and models such as assemblies, meetings, conferences, planning cells, surveys or city observations.

However, the policies performed by various governments were not always supportive towards involving citizens in decision-making processes. What is important is that new policies are pro-active and there is an opportunity for change.

Therefore the aim of the paper was to describe the context between the deliberation processes, empowering citizens, building trust in the local authorities and the relevance of it. An additional aim was to provide evidence that building a dialogue between local governance and citizens can be essential for future sustainable development. The research was based on statistical analyses, extensive literature study and a benchmark based on an implemental approach in the case study of Warsaw.

\section{Statistical analyses of the level of participation in the European Union}

The European Commission published five priorities of Cohesion Policy in 2020, listed as Smarter Europe, Greener and Carbon-Free Europe, Connected Europe, Social Europe and Europe Closer to Citizens. Given that all the priorities are significant for sustainable development and can impact on the quality of life, the final two are essential for empowering citizens. 
The Social Europe priority is intended to support skills, social inclusion, education, quality employment, equal access to healthcare and social inclusion (European Commission, 2020).

Europe Closer to Citizens is based on giving importance to sustainable urban development and locally-led development (European Commission, 2020). More importance should be given to supporting the role of the cities and participatory and multi-level governance (Ferry, 2019).

There are different policies and methods that could help in achieving these aims. Participation is one of the techniques that deserves attention, being very valuable for democratic governance and sustainable growth and development.

The level of participation in the European Union is not the highest, and what is more it is decreasing (Figure 1).

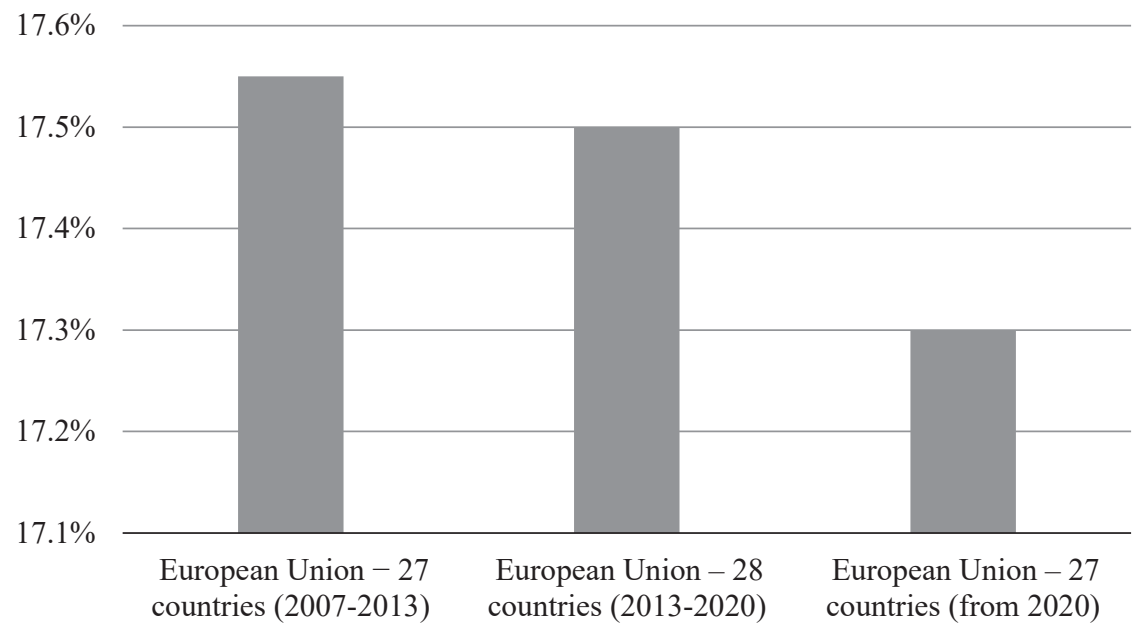

Fig. 1. Participation in formal or informal voluntary activities or citizenship by different factors and time in the European Union

Source: own elaboration based on Eurostat.

However, in the distribution of the EU countries, it is visible that $36 \%$ of them show participation at a level higher than $20 \%$ of society (Figure 2). The most participative citizens are statistically typical of the Netherlands (53\%), Sweden $(50.7 \%)$ and Finland (49.1\%). There are statistics based on other factors (e.g. degree of urbanization) that demonstrate extremely high levels of participation (the Netherlands (82.3\%), Finland (74\%), and Sweden (70\%)).

Another issue that should be considered in the context of empowering citizens is trust in the governance. EU countries do not reach a high percentage for this factor, as shown by statistical analyses (Figure 3 ). 


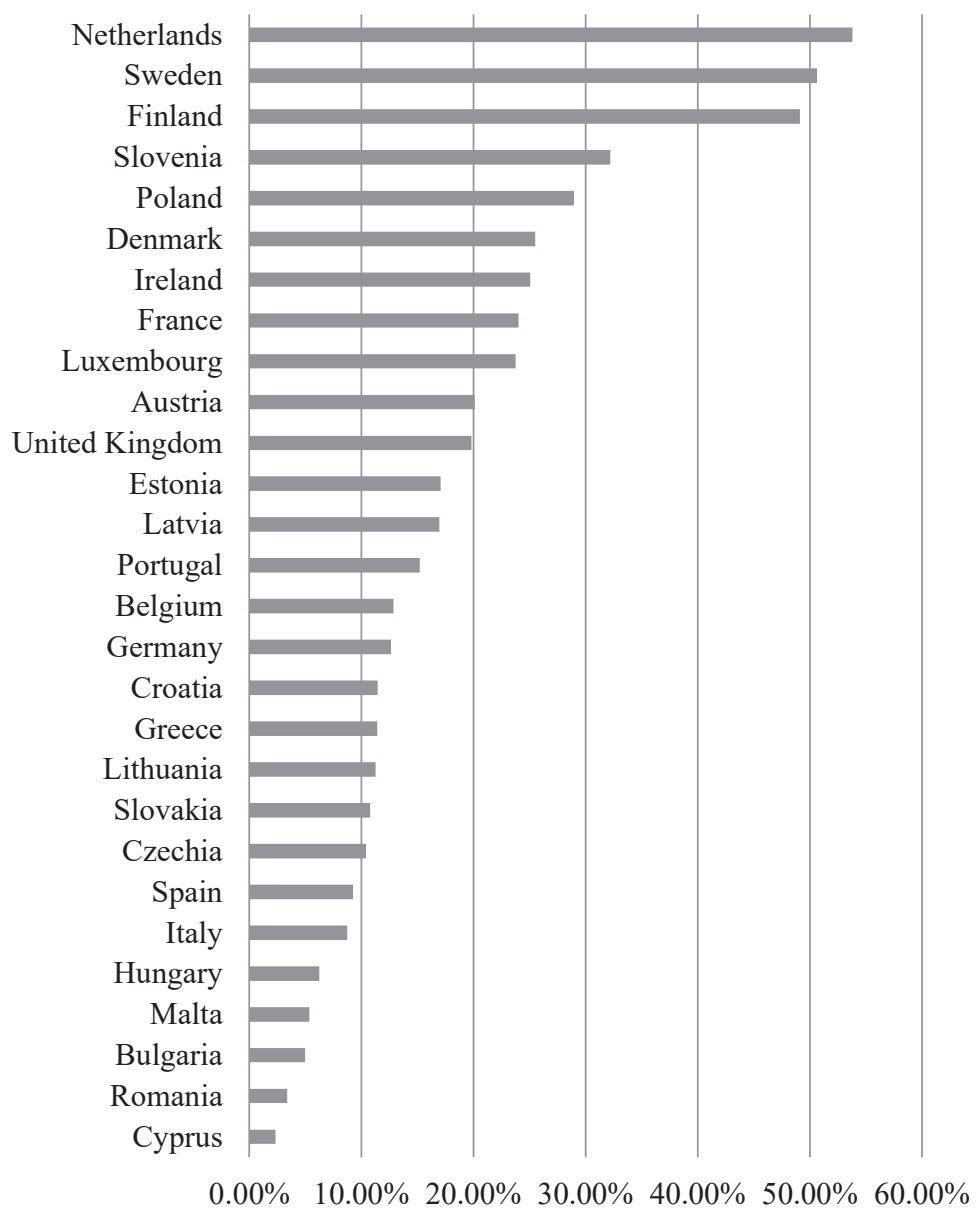

Fig. 2. Participation in formal or informal voluntary activities or citizenship by different countries in the European Union in 2020

Source: own elaboration based on Eurostat.

There is a connection between willingness to participate and trust in governance. Countries with a high percentage of participation of citizens were usually those that presented higher levels of trust (Figure 4).

Why is it so important? To understand that, it is necessary to pay attention to more aspects. The OECD prepared a report about deliberation processes in terms of empowering citizens (OECD, 2020). Following the research, local governments can achieve more trust if they care about participation. Thus, providing the possibility of making decisions by local people is the most significant issue for empowering citizens. 


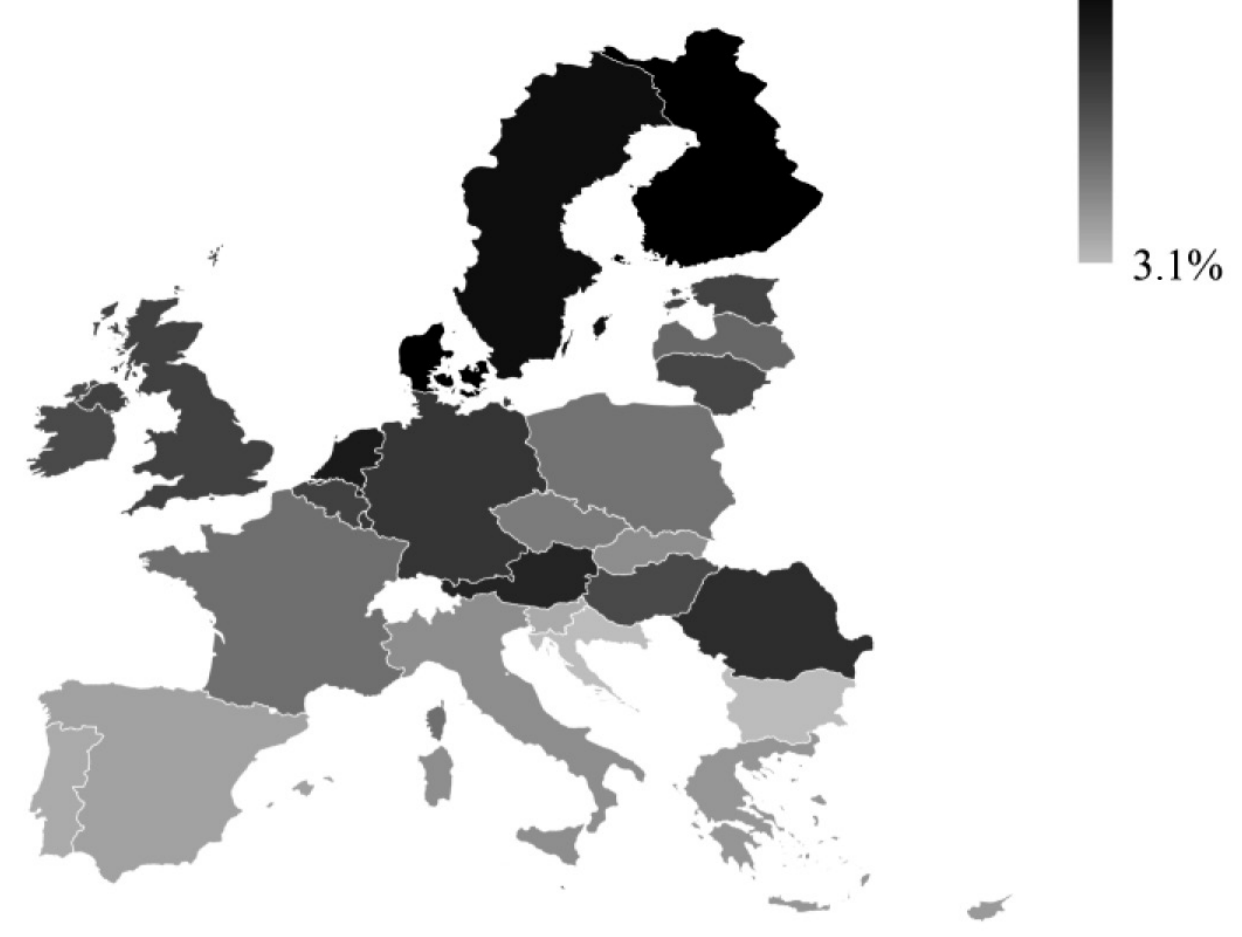

Fig. 3. Trust in the governance in the European Union from 2020

Source: own elaboration based on Eurostat.

However, there are exceptions such as Cyprus, Romania and Malta, where the level of trust is much higher than the will for participation processes. This can be seen also in Slovenia, where the level of participation is one of the highest in Europe whereas trust in governance is quite low (Figure 4). This may be caused by different factors such as relational capital (Aula \& Harmaakorpi, 2008; Capello, 2001; Joston \& Lane, 2008).

Relational capital is about the quality of the network, the connections or relations between its users (Aula \& Harmaakorpi, 2008). It is also strongly linked to trust (to other members of the network) and commitment (Pil \& Leana, 2006). Societies based on the trust are those most willing to act collectively, and exchange information - especially high quality information (Bullen \& Onyx, 2000; Coleman, 1990; Pil \& Leana, 2006). They are also more open for cooperation and setting common goals. 
The literature review also shows that the societies with a poor quality of relational capital are more polarized (Caragliu, Del Bo, \& Nijkamp, 2011). The consequence of this is the lesser ability or willingness to join any collective actions or to participate in different processes.

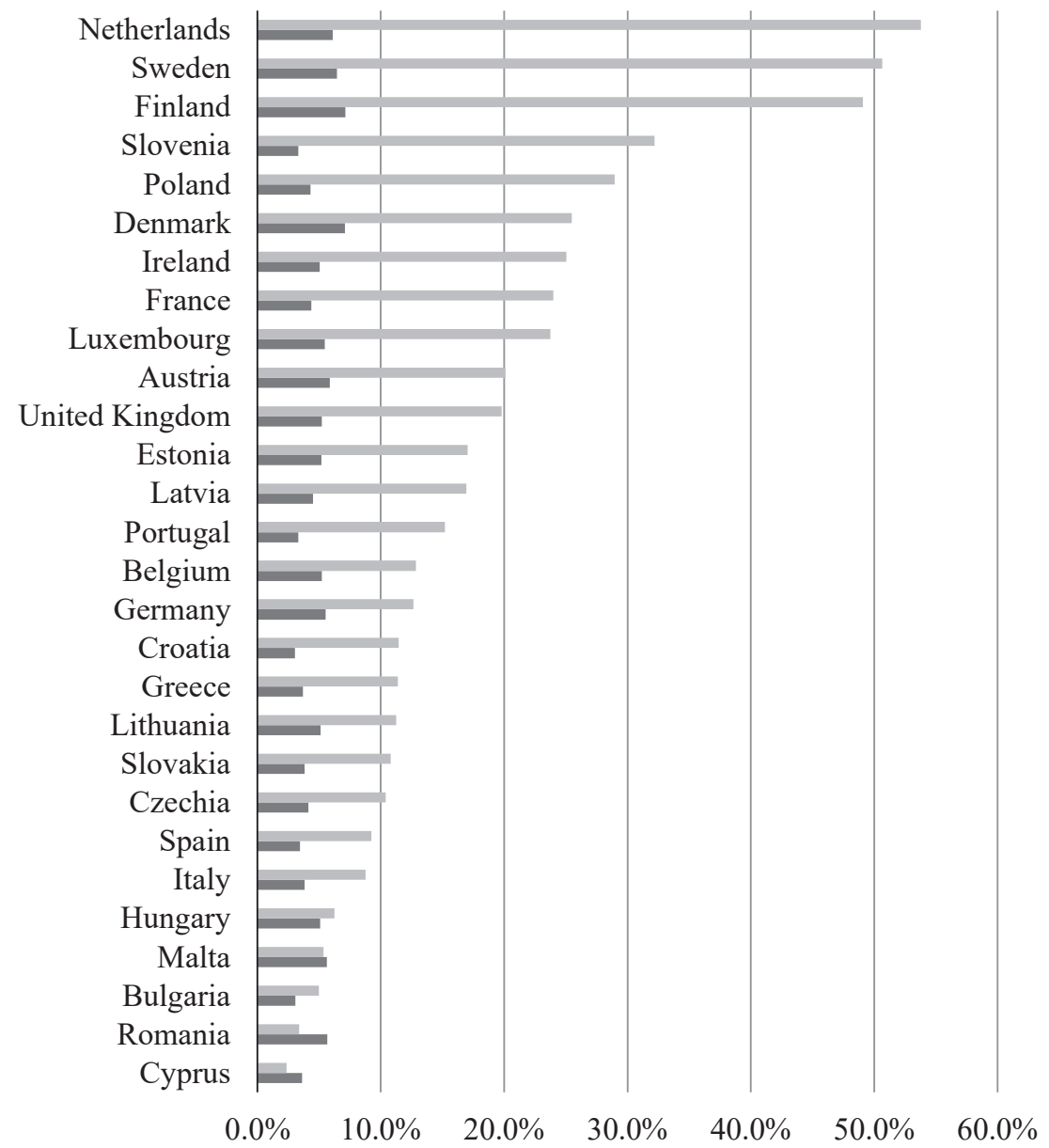

Participation in formal or informal voluntary activities, or active citizenship

- Trust in the governance

Fig. 4. Participation in formal or informal voluntary activities or citizenship versus trust in the governance by different countries in the European Union in 2020

Source: own elaboration based on Eurostat. 


\section{Social innovation in the context of empowering citizens}

Social innovation was initially described and examined by many authors, e.g. Weber and Schumpeter (Schumpeter, 2003; Weber, 1968). Following the theoretical background, social innovation may be seen in two perspectives. The first one says there are different processes (connected to society and economics) that have common characteristics but they "cannot be summarized into a simple model that has any explanatory or predictive power"(Bureau of European Policy Advisers, 2010). The second approach presents social innovation as a tool that may be helpful in reacting to dynamic changes or challenges (Bureau of European Policy Advisers, 2010).

According to different definitions, social innovation can be an instrument supporting the ability of society to take action (Capello, 2011; Coleman, 1990; Pil \& Leana, 2006).

As mentioned before, giving the possibility of making decisions by citizens is quite important in policy-making. One of the processes that accompany participation is deliberation, seen as a new form of governance that consists in involvement in decision-making processes.

There are 11 principles regarding implementing solutions based on deliberation (OECD, 2020):

1. The problem should be specified as a question that reflects the real need.

2. The information about the process should be convenient to find. It has a special meaning for encouraging more stakeholders to participate and gives the possibility of public learning.

3. Participants should have the opportunity to meet (a minimum of four days) and learn, collect recommendations and discuss them.

4. The privacy of participants should be respected. This is really important for preserving their independence.

5. The coordinating team needs to be available to be contacted.

6. Participants should be chosen by random sampling methods to ensure they are representatives of the general public that reflects the real demographic profile of this community.

7. The process should be achievable to everyone following inclusiveness.

8. The authorities should encourage and make it available to monitor and report any recommendations for the general public during the entire process.

9. Participants should have the possibility to gain relevant expertise and evidence, and to ask for needed information even if it is additional.

10. Deliberation in groups should be supported with considering different perspectives, active learning, making room for speaking and mixing variable formats.

11. The whole process should be evaluated following these principles. 
Table 1. Different models of deliberative processes

\begin{tabular}{|c|c|c|c|c|c|c|c|}
\hline & $\begin{array}{l}\text { Average } \\
\text { no. of } \\
\text { participants } \\
\text { per panel }\end{array}$ & $\begin{array}{l}\text { Average } \\
\text { length of } \\
\text { meetings }\end{array}$ & $\begin{array}{l}\text { Average } \\
\text { length } \\
\text { from first } \\
\text { to last } \\
\text { meeting }\end{array}$ & $\begin{array}{l}\text { No. } \\
\text { of times } \\
\text { used to } \\
\text { date } \\
\text { process } \\
\text { (panels) }\end{array}$ & $\begin{array}{l}\text { Used by } \\
\text { countries }\end{array}$ & Result & $\begin{array}{l}\text { Policy questions } \\
\text { addressed } \\
\text { to date }\end{array}$ \\
\hline 1 & 2 & 3 & 4 & 5 & 6 & 7 & 8 \\
\hline \multicolumn{8}{|c|}{ Informed citizen recommendations on policy questions } \\
\hline $\begin{array}{l}\text { 1. Citizens' } \\
\text { Assembly }\end{array}$ & 90 & 18.8 days & 47 weeks & $6(6)$ & $\begin{array}{l}\text { Canada, } \\
\text { Ireland }\end{array}$ & $\begin{array}{l}\text { Detailed } \\
\text { collective } \\
\text { recommen- } \\
\text { dations }\end{array}$ & $\begin{array}{l}\text { Electoral } \\
\text { reforms, } \\
\text { institutional } \\
\text { setup, } \\
\text { constitutional } \\
\text { questions }\end{array}$ \\
\hline $\begin{array}{l}\text { 2. Citizens' } \\
\text { Jury/Panel }\end{array}$ & 34 & 4.1 days & 5 weeks & $115(168)$ & $\begin{array}{l}\text { Austria, } \\
\text { Australia, } \\
\text { Belgium, } \\
\text { Canada, } \\
\text { France, } \\
\text { Poland, } \\
\text { Spain, UK, } \\
\text { USA }\end{array}$ & \multirow[t]{4}{*}{$\begin{array}{l}\text { Collective } \\
\text { recommen- } \\
\text { dations }\end{array}$} & $\begin{array}{l}\text { Broad range } \\
\text { of topics. Most } \\
\text { common: } \\
\text { infrastructure, } \\
\text { health, urban } \\
\text { planning, } \\
\text { environment. }\end{array}$ \\
\hline $\begin{array}{l}\text { a) Consecutive } \\
\text { day meetings }\end{array}$ & 30 & 3.4 days & 0 weeks & $23(40)$ & Canada & & $\begin{array}{l}\text { Ongoing } \\
\text { processes } \\
\text { mandated to } \\
\text { provide input on } \\
\text { various } \\
\text { questions when } \\
\text { public authority } \\
\text { is in need. }\end{array}$ \\
\hline $\begin{array}{l}\text { b) Non- } \\
\text { consecutive } \\
\text { day meetings }\end{array}$ & 35 & 4.1 days & 7 weeks & $90(126)$ & & & \\
\hline c) Ongoing & 32 & 11 days & 2 years & $2(2)$ & & & \\
\hline $\begin{array}{l}\text { 3. Consensus } \\
\text { Conference }\end{array}$ & 16 & 4.0 days & 2 weeks & $19(19)$ & $\begin{array}{l}\text { Australia, } \\
\text { Austria, } \\
\text { Denmark, } \\
\text { France, } \\
\text { Norway, } \\
\text { United } \\
\text { Kingdom }\end{array}$ & $\begin{array}{l}\text { Collective } \\
\text { recommen- } \\
\text { dations }\end{array}$ & $\begin{array}{l}\text { New technology, } \\
\text { environment, } \\
\text { health }\end{array}$ \\
\hline $\begin{array}{l}\text { 4. Planning } \\
\text { Cell }\end{array}$ & 24 & 3.2 days & 0 weeks & $57(247)$ & $\begin{array}{l}\text { Germany, } \\
\text { Japan }\end{array}$ & $\begin{array}{l}\text { Collective } \\
\text { position } \\
\text { report / } \\
\text { citizens' } \\
\text { report }\end{array}$ & $\begin{array}{l}\text { Most common } \\
\text { use for urban } \\
\text { planning, but } \\
\text { also other topics }\end{array}$ \\
\hline
\end{tabular}


Table 1, cont.

\begin{tabular}{|c|c|c|c|c|c|c|c|}
\hline 1 & 2 & 3 & 4 & 5 & 6 & 7 & 8 \\
\hline \multicolumn{8}{|c|}{ Citizen opinion on policy questions } \\
\hline 5. G1000 & 346 & 1.7 days & 4 weeks & $12(12)$ & $\begin{array}{l}\text { The } \\
\text { Netherlands, } \\
\text { Spain }\end{array}$ & $\begin{array}{l}\text { Votes on } \\
\text { proposals }\end{array}$ & $\begin{array}{l}\text { Strategic } \\
\text { planning: } \\
\text { developing } \\
\text { a future vision } \\
\text { for the city }\end{array}$ \\
\hline $\begin{array}{l}\text { 6. Citizens' } \\
\text { Council }\end{array}$ & 15 & 1.7 days & 1 week & $14(24)$ & $\begin{array}{l}\text { Austria, } \\
\text { Germany }\end{array}$ & $\begin{array}{l}\text { Collective } \\
\text { recommen- } \\
\text { dations }\end{array}$ & $\begin{array}{l}\text { Various topics, } \\
\text { most common: } \\
\text { environment, } \\
\text { strategic } \\
\text { planning }\end{array}$ \\
\hline $\begin{array}{l}\text { 7. Citizens' } \\
\text { Dialogues }\end{array}$ & 148 & 2.1 days & 4 weeks & 38 (112) & Globally & $\begin{array}{l}\text { Broad ideas / } \\
\text { recommen- } \\
\text { dations }\end{array}$ & $\begin{array}{l}\text { Various topics, } \\
\text { often several } \\
\text { addressed at } \\
\text { once }\end{array}$ \\
\hline $\begin{array}{l}\text { 8. Deliberative } \\
\text { Poll/Survey }\end{array}$ & 226 & 1.6 days & 0 weeks & $14(15)$ & $\begin{array}{l}\text { Argentina, } \\
\text { Australia, } \\
\text { Brazil, } \\
\text { China, Italy, } \\
\text { Japan, } \\
\text { Korea, } \\
\text { Mongolia, } \\
\text { USA }\end{array}$ & $\begin{array}{l}\text { Survey } \\
\text { opinions and } \\
\text { opinion } \\
\text { changes }\end{array}$ & Various topics \\
\hline 9. WWViews & 120 & 1 day & 0 weeks & $4(150)$ & Globally & $\begin{array}{l}\text { Votes on } \\
\text { proposals }\end{array}$ & $\begin{array}{l}\text { Environment } \\
\text { issues on } \\
\text { a global scale }\end{array}$ \\
\hline \multicolumn{8}{|c|}{ Informed citizen evaluation of ballot measures } \\
\hline $\begin{array}{l}\text { 10. Citizens' } \\
\text { Initiative } \\
\text { Review }\end{array}$ & 22 & 4.4 days & O weeks & $8(8)$ & USA & $\begin{array}{l}\text { Collective } \\
\text { statement of } \\
\text { key facts }\end{array}$ & Various topics \\
\hline \multicolumn{8}{|c|}{ Permanent deliberative bodies } \\
\hline $\begin{array}{l}\text { 11. Ostbelgien } \\
\text { model }\end{array}$ & 24 & $\begin{array}{l}\text { No data } \\
\text { yet }\end{array}$ & 1.5 years & $1(1)$ & Belgium & $\begin{array}{l}\text { Collective } \\
\text { recommen- } \\
\text { dations }\end{array}$ & $\begin{array}{l}\text { Mandate to set } \\
\text { the agenda and } \\
\text { initiate citizens' } \\
\text { panels }\end{array}$ \\
\hline $\begin{array}{l}\text { 12. City } \\
\text { Observatory }\end{array}$ & 49 & 8 days & 1 year & $1(1)$ & Spain & $\begin{array}{l}\text { Decisions on } \\
\text { citizen } \\
\text { proposals }\end{array}$ & $\begin{array}{l}\text { Mandate to } \\
\text { evaluate citizen } \\
\text { proposals and } \\
\text { suggest them for } \\
\text { referenda }\end{array}$ \\
\hline
\end{tabular}

Source: (OECD, 2020).

What is significant, deliberation models can be really diverse. There is no 'ideal' version of the deliberation process (Table 1). 


\section{Deliberation processes using the example of the Citizens' Panel in Warsaw}

In regard of deliberative processes models, there are many e.g. Citizens' Panel. This method is quite new in Poland, only five cities have organized this form of dialogue between citizens and the local governance.

Three NGOs (Fundacja Pracownia Badań i Innowacji Społecznych „Stocznia”, Fundacja Pole Dialogu and Fundacja Civis Polonus) with the cooperation of the municipality of Warsaw organized the Climate Panel in 2020. Due to COVID-19 conditions, the entire process was held on-line. That was the first challenge as the organizers needed to support participants that would be digitally excluded by offering the help of assistants, a place to work outside of home or providing the necessary equipment (Fundacja Civis Polonus..., 2021).

The main subject of the panel was: "How to increase the energy efficiency of Warsaw and the share of renewable energy sources in the city's energy balance?"

There were also some supplementary questions (Fundacja Civis Polonus..., 2021):

- How to ensure thermal and ventilation comfort in buildings with lower energy consumption?

- What should be the standards for building new buildings and how to modernize the existing ones?

- How to act within cooperatives and housing communities for more effective energy management in buildings?

- How to finance energy investments?

- What changes to introduce in city lighting?

- What can be renewable energy sources for Warsaw and what is connected with it?

Despite the difficulties caused by the pandemic, the panel was organized with the help of digital tools. Meetings took place online in groups of citizens representing all cross-section of Warsaw society. What is more, the most important sessions were transmitted live in social media and reported in local and municipal media.

The programme of the panel included one inauguration meeting, two educational (participants could learn from different experts) and two meetings for discussions, the last one provided voting for solutions.

The result was preparing a collection of recommendations for mitigation and adaptation processes in the context of climate change. The panelists chose some ideas that would help in the saving, more efficient use, and the production of energy in the city. Additionally it discussed how to develop the city in the case of supporting the achievement of the goal of reducing greenhouse gas emissions in Warsaw by at least $40 \%$ by 2030 , and climate neutrality by 2050 (Fundacja Civis Polonus..., 2021). 
The most important issues for the participants were linked to spatial planning, education, energy management in buildings, better ventilation in schools and efficient use of hot water, green standards, including energy standards for buildings, cooperation with Warsaw's neighbors, new buildings and monuments and renewable energy sources energy, including energy communities (Fundacja Civis Polonus..., 2021).

Moreover, the participants of the panel voted for some recommendations concerning the Warsaw Climate Panel: planning the monitoring of the implementation of the panel's recommendations, delivering the panel's recommendations to the designers of the study of the conditions and directions of spatial development in Warsaw, and active involvement of the municipality in promoting the voted recommendations of the Warsaw Climate Panel as part of the Green City Action Plan.

However, the most significant outcome of this event was the fact that the panel was organized at the request of the local community and NGOs, which meant that there was a need to take such essential issues under consideration, mostly from the viewpoint of the citizens themselves.

\section{Conclusions}

Empowering citizens is a truly multidimensional problem, and this paper presents just a small fragment of it.

One of the most important outcomes of this research was creating a recommendation for policy makers that was based on observation. Building a dialogue between local governance and citizens can be significant for future sustainable development, as seen in the example of Warsaw. The citizens had the opportunity to change something, to take care and responsibility for issues like climate change, which resulted in a complex collection of ideas.

Communities that are strongly bound together, and their members are more cooperative may be more resilient and participative. It is important to build high quality social networks.

This output may be part of a new policy created by the municipality that may be probably eagerly accepted by citizens. Moreover, this kind of actions is crucial for building trust in the governance.

Most likely, if the municipality continues involving citizens in decision-making processes, they will be more likely to take interest in other forms of participation.

The policy is not just for its own sake. It should be a tool to improve the level of living standards. 


\section{References}

Aula, P., \& Harmaakorpi, V. (2008). An innovative milieu: A view on regional reputation building. Regional Studies, 42(4), 523-538. https://doi.org/10.1080/00343400701543207

Bullen, P., \& Onyx, J. (2000). Measuring social capital in five communities. Journal Applied Behavioral Sciences, 36(1), 23-42.

Bureau of European Policy Advisers. (2010). Empowering people, driving change. Social Innovation in the European Union. Retrieved May 15, 2020 from https:/ec.europa.eu/migrant-integration/ librarydoc/empowering-people-driving-change-social-innovation-in-the-european-union

Capello, R. (2001). Spatial and Sectoral Characteristics of Relational Capital in Innovation Activity(41st Congress of the European Regional Science Association: "European Regional Development Issues in the New Millennium and their Impact on Economic Policy", 29 August - 1 September 2001), Zagreb, Croatia, European Regional Science Association (ERSA), Louvain-la-Neuve.

Caragliu, A., Del Bo, C., \& Nijkamp, P. (2011). Smart cities in Europe. Journal of Urban Technology, 18(2), 65-82. https://doi.org/1080/10630732.2011.601117

Coleman, J. S. (1990). Foundations of social theory. Cambridge, MA: Harvard University Press.

European Commission. (2020). New cohesion policy. Retrieved May 20, 2020 from https://ec.europa. eu/regional_policy/en/2021_2027/

Ferry, M. (2019). Integrated territorial investments as an effective tool of the cohesion policy. European Parliament. Retrieved May 15, 2020 from https://www.europarl.europa.eu/cmsdata/162823/ 25032019_CONT_Briefing_ITI_Final.pdf

Fundacja Civis Polonus, Fundacja Pole Dialogu, Fundacja Stocznia. (2021). Warszawski Panel Klimatyczny. Raport z realizacji. Retrieved May 29, 2020 from https://poledialogu.org.pl/wp-content/ uploads/2021/02/WPK-raport-z-realizacji.pdf

Joston, K. A., \& Lane, A. B. (2018). Building relational capital: the contribution of episodic and relational community engagement. Public Relations Review, 44, 633-644. https://doi.org/10.1016/j. pubrev.2018.10.006

OECD. (2020). Innovative citizen participation and new democratic institutions. Retrieved May 20, 2020 from https://www.oecd.org/gov/innovative-citizen-participation-and-new-democratic-institutions-339306da-en.htm

Pil, F. K., \& Leana, C. R. (2006). Social capital and organizational performance: Evidence from urban public schools. Organization Science, 17(3), INFORMS, 353-366. https://doi.org/10.1287/ orsc. 1060.0191

Schumpeter, J. (2003). The theory of economic development [translation of Theorie der wirtschaftlichen Entwicklung by Ursula Backhaus]. Dordrecht: Kluwer Academic Publishers.

Weber, M. (1968). Economy and society: An outline of interpretative sociology. G. Roth, C. Wittich (Eds.). Berkeley, Los Angeles and London: University of California Press. 